\title{
Effect of Bambara groundnut (Vigna subterranea) consumption on biomarkers of oxidative stress in alloxan-induced diabetic Wistar rats
}

\author{
Olanipekun, O. T. ${ }^{1}$, Omenna, E. C. ${ }^{2 *}$, Adeniyi, G. A. ${ }^{3}$ and Adedeji, F. T. ${ }^{3}$ \\ 1Product Development Program, Institute of Agricultural Research and Training, Obafemi Awolowo University, Nigeria. \\ ${ }^{2}$ Kenaf and Jute Improvement Program, Institute of Agricultural Research and Training, Obafemi Awolowo University, \\ Nigeria. \\ ${ }^{3}$ Department of Family Nutrition and Consumer Sciences, Faculty of Agriculture, Obafemi Awolowo University, Nigeria. \\ ${ }^{*}$ Corresponding author. Email: emmanuelomenna@gmail.com \\ Copyright (@) 2019 Olanipekun et al. This article remains permanently open access under the terms of the Creative Commons Attribution License 4.0, \\ which permits unrestricted use, distribution, and reproduction in any medium, provided the original work is properly cited.
}

Received 12th February, 2019; Accepted 29th April, 2019

\begin{abstract}
This study investigated the effect of consumption of diet supplemented with Bambara-groundnut (BGN) on some biomarkers of oxidative stress in diabetic induced rats. A total of 24 apparently healthy adult albino wistar rats were assembled and divided into 4 groups A-D; group A (Non diabetic rats, fed on normal diet), B (Diabetic rats fed on normal diet), $C$ (Diabetic rats fed on 10\% Bambara-groundnut diet), D (Diabetic rats fed on Nitrogen free diet) with each group consisting of 6 rats respectively. After 4 weeks of feeding, rats were sacrificed and blood collected into heparin container and used for laboratory analysis. Superoxide dismutase (SOD), glutathione peroxidase (GSHPER), alkaline phosphatase (ALP), alanine amino transferase (ALT), aspartate transaminase (AST) were assayed for using standard laboratory methods. The result showed that Group $C$ rats had the lowest post-feeding glucose concentration (75 mg/dl). AST, ALT, and ALP were elevated in diabetic induced rats; but, treatment with Bambara-groundnut diet reversed the parameters close to control. The highest levels of SOD and GSHPER were found in group $C$ rats while the group $B$ rats had the highest oxidative stress. It can be concluded that Bambara-groundnut diet modulated and ameliorated the oxidative stress in diabetic rats.
\end{abstract}

Keywords: Alanine amino transferase, alkaline phosphatase, aspartate transaminase, Bambara groundnut, diabetic rats, oxidative stress, oxidative stress biomarkers.

\section{INTRODUCTION}

The term diabetes mellitus describes a metabolic disorder of multiple aetiology; characterized by chronic hyperglycaemia with disturbances of carbohydrate, fat and protein metabolism; resulting from defects in insulin secretion, insulin action, or both (Ejike et al., 2015). The effects of diabetes mellitus include long-term damage, dysfunction and failure of various organs. Diabetes mellitus may present with characteristic symptoms such as polyphagia, polyuria, blurring of vision, and weight loss (Olokoba et al., 2012). Diabetic complications are linked to hyperglycaemia induced oxidative stress, which eventually overcomes the endogenous antioxidant defense system within the human and animal body. Long term effect of diabetes mellitus has been reported to cause some chronic complications like high blood pressure, heart attack and stroke. Clinical and animal studies on type 2 diabetes have shown inverse correlation between oxidative stress and insulin sensitivity (Oztasan, 2013). The management of diabetes mellitus includes strategies to reduce hyperglycemia and its attendant oxidative stress; the strategies includes regular physical exercises, eating carefully controlled diet, taking medications as prescribed and losing excessive weight. However, recent reports suggest antioxidant treatment may be beneficial 
(Ademiluyi and Oboh, 2012; Oztassan, 2013). Oxidative stress occurs when there is excessive production of free radicals due to insufficiency of the antioxidant response system in a body (Salim, 2017), leading to cellular injury and ultimately organ failure (Jadela et al., 2017). The liver is a very important organ in the body, as it is responsible for many vital life functions such as metabolism of nutrients, excretion of bilirubin, hormones, cholesterol and drugs. It is also responsible for blood detoxification and purification. Aspartate transaminase (AST), Alkaline phosphatase (ALP) and Alanine transaminase (ALT) are biomarkers of liver injury used in investigating the integrity of the liver in apparently healthy patients (Ahmed et al., 2018).

Plant foods and products which are used trado-medically are now receiving research attention to be able to ascertain and document their therapeutic abilities. In the management of diabetes, the therapeutic properties of these plants have been hinged on the abundance of phytochemicals like polyphenols which possess strong antioxidant properties (Ademiluyi and Oboh, 2012). Legumes are known to be rich in polyphenols (Oboh, 2006). Legumes abound in many parts of Africa, where they are traditionally major components of many food preparations; in African trado-medical practice, legumes are components of many preparations used for the management of diabetes (Jideani and Diedrick, 2014). Legumes which are well utilized in Nigeria include cowpea (popularly called beans), groundnut, and soybeans; however, many other legumes are still underutilized or unexploited. Bambara groundnut is a legume that is still underutilized.

Bambara groundnut (Vigna subterranea) is classified under the family Leguminosae, sub-family Faboidea and genus Vigna. It is a seed of Africa origin used locally as a vegetable and it was first found in West Africa (Bamshaiye et al., 2011). Bambara groundnut is a crop with great potential to sustain the dietary needs of both urban and rural communities (Jideani and Diedrick, 2014). Its seed consist of 49.0 to $63.5 \%$ carbohydrate, 15.0 to $25 \%$ protein, 4.5 to $7.4 \%$ fat, 5.2 to $6.4 \%$ fibre, 3.2 to $4.4 \%$ ash and $2 \%$ mineral (Bamshaiye et al., 2011). The traditional uses of Bambara groundnut to treat several ailments are noteworthy, and present a gap for detailed study on the therapeutic and pharmaceutical value of the crop (Harris et al., 2018). Jideani and Diedrick (2014) reported that the medicinal role of Bambara groundnut is mainly based on information obtained from communities in several parts of Africa where this crop is reportedly responsible and useful for treatment of various ailments. For example as a treatment for diarrhoea, a mixture of Bambara groundnut and water from boiled maize are consumed; to alleviate the nausea associated with pregnancy, Bambara groundnut seeds are chewed and swallowed by pregnant women (DPP, 2011). Other prophylactic and therapeutic use of Bambara groundnut includes use against protein deficiency kwashiorkor, treatment of veneral diseases, treatment of polymenorrhea (roasted BGN seeds are used); treatment for internal bruising, treatment of cataracts (mixture of water and crushed BGN seeds are used (Koné et al., 2011). The objective of this study is to assess the effect of Bambara groundnut consumption on biomarkers of oxidative stress in diabetic induced rats in order to ascertain and document its effectiveness in this regard.

\section{MATERIALS AND METHODS}

\section{Materials}

The study was carried out at the Institute of Agricultural Research and Training, Obafemi Awolowo University Ibadan; Oyo State Nigeria. Bambara groundnut seeds were sourced locally from Bodija market in Ibadan. All the reagents and chemicals used were of analytical grades, distilled water was used for all laboratory analyses.

\section{Ethical approval}

The experimental study was approved by the research committee of Institute of Agricultural Research and Training, Obafemi Awolowo University, Nigeria.

\section{Laboratory animals}

Twenty four male healthy Wistar albino rats weighing between 200 to $220 \mathrm{~g}$, were obtained from Covenant farm, Ibadan. The handling and use of the animals were in accordance with National Institute of Health $(\mathrm{NIH})$ guide for the care and use of laboratory animals $(\mathrm{NIH}, 2011)$.

\section{Acclimatization of animals}

The experimental animals were housed in the rat house of Institute of Agricultural Research and Training (IAR\&T) and grouped in 4 standard cages of 6 rats each; kept at room temperature of $27^{\circ} \mathrm{C}$, humidity (55\%) and 12 hours light and darkness cycle respectively, under clean environmental conditions. The cages (labeled A-D) were designed for the separate collection of faeces and urine and monitoring of food intake. The rats were acclimatized on commercial rat chow and water ad libitum for seven days.

\section{Processing of Bambara groundnut seeds}

Bambara groundnut seeds were processed by a modified method of Farinde et al. (2018). The seeds were weighed and sorted to remove foreign substances. The seeds were 
washed with water, and cooked for 1 and half hours. The boiled Bambara groundnut seeds were oven dried at $60^{\circ} \mathrm{C}$ for 4 hours, and milled using a Philips laboratory blender (HR3652/01, UK). The flour was sieved using a $60 \mathrm{~mm}$ mesh sieve (British standard), and packed in plastic container sealed with aluminum foil, and was stored at room temperature prior to analyses. The processed Bambara groundnut seeds were referred to as Bambara groundnut seed flour (BGNSF).

\section{Induction of diabetes}

Diabetes mellitus was induced in overnight-fasted rats by the method of (Jarald et al., 2013). A single intra-peritoneal injection of a freshly prepared alloxan monohydrate (equivalence of $150 \mathrm{mg}$ alloxan monohydrate $/ \mathrm{kg}$ bodyweight rat) dissolved in ice cold $0.9 \% \mathrm{NaCl}$ solution. Diabetes state was checked after 72 hours of induction; this was done by monitoring glucose level of the rats using ACCU-CHECK glucometer (Roche Diagnostics, Germany). Blood sample of the rats was taken by tail vein puncture. Animals with blood glucose level $\geq 200 \mathrm{mg} / \mathrm{dl}$ were used for this study (Ademiluyi and Oboh, 2012). Rats in group A served as control, and were injected with sterile water for injection.

\section{Experimental diet}

The experimental diet was compounded as in Table 1. The rats were given the experimental diet for four weeks.

\section{Protein quality of Bambara groundnut seed flour}

The protein quality study was done as described by ljarotimi and Keshinro (2012). The rats were fed as shown in Table1 for four weeks. Urine samples were collected daily from each cage in a small urine container which contained about $1 \mathrm{~cm}$ Conc. $\mathrm{H}_{2} \mathrm{SO}_{4}$, Faecal samples were collected daily from each cage. The faecal samples were weighed, dried, and milled. Samples of the diet, faeces and urine of the rats were analyzed for Nitrogen by Kjedhal method (AOAC, 2000). Weight gained by the animals, faecal and urine Nitrogen values were used to calculate the following parameters for protein quality:

$$
\begin{aligned}
& \text { Biological value }(\mathrm{BV})=\frac{\mathrm{Ni}-(\mathrm{Nf}-\mathrm{Nef})-(\mathrm{Nu}-\mathrm{Neu})}{\mathrm{Ni}-(\mathrm{Nf}-\mathrm{Neu})} \times 100 \quad \text { Eqn. } 1 \\
& \text { Food efficiency }(\mathrm{FE})=\frac{\text { Weight gained }}{\text { Food intake }} \quad \text { Eqn. } 2 \\
& \text { Net protein utilization }(\mathrm{NPU})=\frac{\mathrm{Ni}-(\mathrm{Nf}-\mathrm{Nef})-(\mathrm{Nu}-\mathrm{Neu})}{\mathrm{Ni}} \times 100 \quad \text { Eqn. } 3 \\
& \text { Nitrogen retention }(\mathrm{NR})=\mathrm{Ni}-(\mathrm{Nf}-\mathrm{Nef})-(\mathrm{Nu}-\mathrm{Neu}) \quad \text { Eqn. } 4 \\
& \text { True protein digestibility }(\mathrm{TD})=\frac{\mathrm{Ni}-(\mathrm{Nf}-\mathrm{Nef})}{\mathrm{Ni}} \times 100 \quad \text { Eqn. } 5
\end{aligned}
$$

Where: $\mathrm{Ni}=$ nitrogen intake; $\mathrm{Nf}=$ fecal nitrogen; Nef = endogenous fecal nitrogen; $\mathrm{Nu}=$ urinary nitrogen and $\mathrm{Neu}$ $=$ endogenous urinary nitrogen.

\section{Feed intake of rats}

The amount of feed given to each rat group was recorded daily. Before feed was given the following day, the amount of feed left in the feed tray was weighed and recorded. Feed intake of rats in each group was calculated as: Amount of feed given/day - Amount of feed left in feed tray/day.

\section{Body weight determination}

To determine the body weight of each rat, the rat was put in a pre-weighed small container that has been designed for that purpose; and placed on a digital balance (Camry model EK8022). The body weight before feeding on experimental diet (Initial body weight) and after feeding on experimental diet (Final body weight) was taken and recorded. The weight gain of each rat was determined by the formula (Final body weight - Initial body weight). Mean body weight gain was calculated for each group and recorded in gram.

\section{Analytical procedures}

At the end of the feeding trial, rats were sacrificed, and blood collected from the jugular vein into heparin bottles. Plasma was assayed for liver damage marker enzymes; alkaline phosphatase (ALP), alanine aminotransferase (ALT), aspartate amino transferase (AST); using methods described in commercially available kits obtained from Randox Laboratories, UK. Biomarkers of oxidative stress were also assessed in the plasma; superoxide dismutase (SOD) was determined according to the method of Winterbourn et al. (1975) as described by Rotimi et al. (2010). Aliquots $(1.4 \mathrm{~mL})$ of the reaction mixture (comprising $50 \mathrm{mM}$ phosphate buffer [pH 7.4], $20 \mathrm{mM} \mathrm{I-}$ methionine, Triton X-100, $10 \mathrm{mM}$ hydroxylamine hydrochloride, and $50 \mathrm{mM}$ EDTA) were added to $10 \mu \mathrm{L}$ of the sample and incubated at $30^{\circ} \mathrm{C}$ for 5 minutes. $80 \mu \mathrm{L}$ of $50 \mathrm{mM}$ riboflavin was then added, and the tubes exposed to $200-\mathrm{W}$ lamps. After the exposure time, $1 \mathrm{~mL}$ of Greiss reagent was added, and the absorbance of the color formed read at $534 \mathrm{~nm}$. One unit of enzyme activity is defined as the amount of enzyme capable of inhibiting 50\% of nitrite formation under assay conditions.

To measure the activity of Glutathione peroxidase (GSHPER), the reaction mixture contains $2.0 \mathrm{ml}$ of $0.4 \mathrm{M}$ Tris- $\mathrm{HCl}$ buffer, $\mathrm{pH} 7.0 ; 0.01 \mathrm{ml}$ of $10 \mathrm{mM}$ sodium azide, $0.2 \mathrm{ml}$ of enzyme, $10 \mathrm{mM}$ glutathione $(0.2 \mathrm{ml})$ and $0.2 \mathrm{mM}$ $\mathrm{H}_{2} \mathrm{O}_{2}(0.5 \mathrm{ml})$ was incubated at $37^{\circ} \mathrm{C}$ for 10 minutes and the reaction terminated by the addition of $0.4 \mathrm{ml} 10 \%(\mathrm{v} / \mathrm{v})$ 
Table 1. Experimental diet of the rat groups.

\begin{tabular}{lcccc}
\hline Ingredients & Group A & Group B & Group C & Group D \\
\hline Cornstarch (\%) & 81 & 81 & 71 & 91 \\
Salt/mineral mixture (\%) & 4 & 4 & 4 & 4 \\
Fat (\%) & 5 & 5 & 5 & 5 \\
Fish meal (\%) & 10 & 10 & 10 & - \\
BGNSF (\%) & & & 10 & - \\
\hline
\end{tabular}

BGNSF = Bambara groundnut seed flour, GROUP A = Non diabetic rats, normal diet, GROUP B = Diabetic rats, normal diet, GROUP $\mathrm{C}=$ Diabetic rats fed on $10 \%$ of Bambara-groundnut seed flour and GROUP D = Diabetic rats fed on nitrogen free diet.

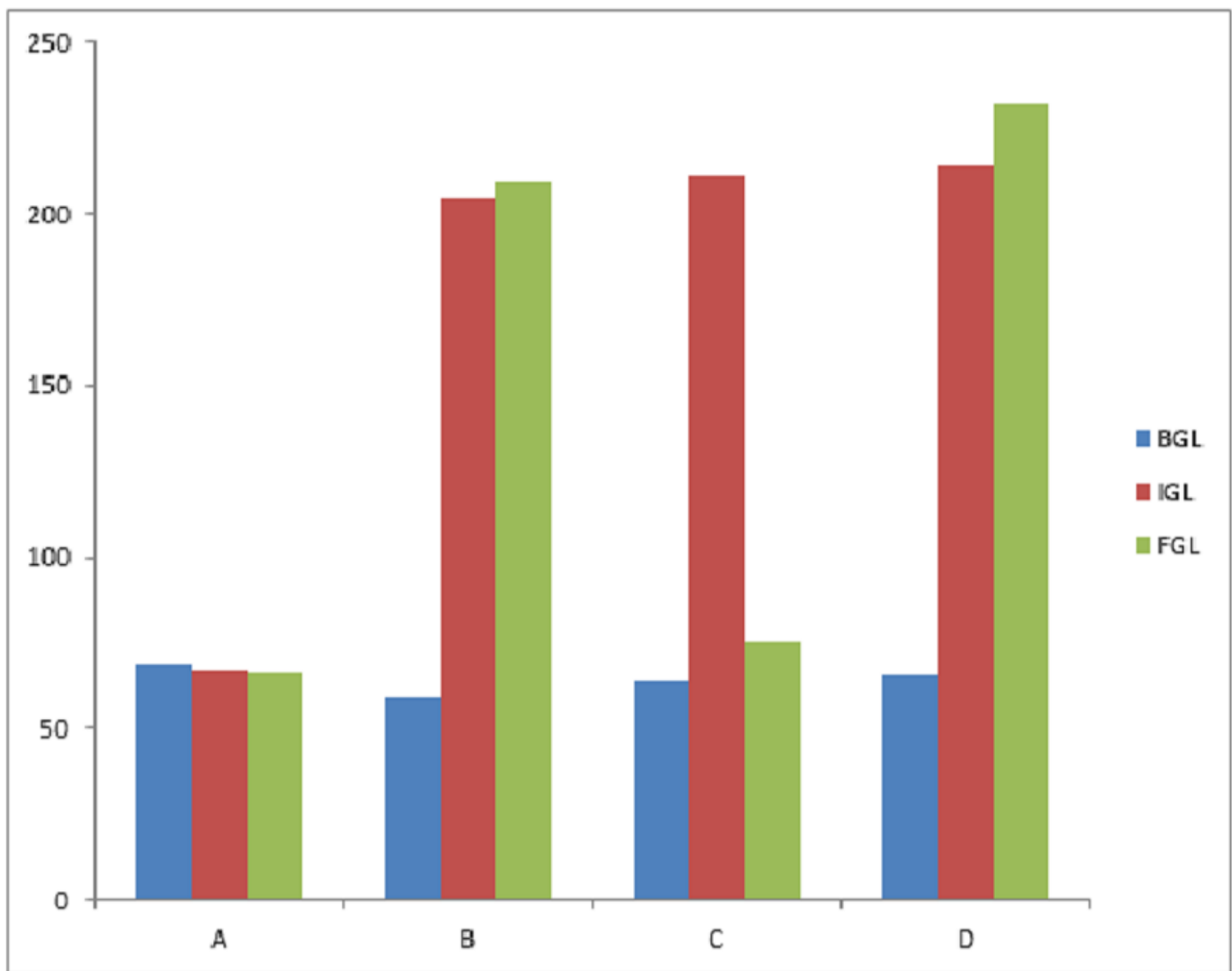

Figure 1. Blood glucose level of rats $(\mathrm{mg} / \mathrm{dl})$. BGL= Baseline glucose level (No induction), IGL = Initial glucose level of diabetic induced rats (pre feeding trial), $F G L=$ Final glucose level of diabetic induced rats (post feeding trial), $A=$ Non diabetic rats fed on normal diet, $B=$ Diabetic rats fed on normal diet, $C=$ Diabetic rats fed on $10 \%$ Bambara groundnut diet and D = Diabetic rat fed on Nitrogen free diet.

TCA. Reaction mixture was then centrifuged at $5000 \mathrm{rpm}$ for 5 minutes. The absorbance of the product was read at $430 \mathrm{~nm}$ and expressed as $\mathrm{nmol} / \mathrm{mg}$ protein.

\section{Data analysis}

Result was expressed as mean \pm standard deviation $(n=6)$ and the mean was compared using one-way analysis of variance (ANOVA) followed by Duncan's multiple range test, using Statistical Package for Social Science (SPSS)
10.0 for Windows. The significance level was taken at $p<0.05$.

\section{RESULTS AND DISCUSSION}

In this study, there was no significant difference $(p>0.05)$ in the base line glucose level of all rat groups (Figure 1). This was expected since all the rats were bought from the same farm, and had been fed on the same diet under the same condition. After the induction of diabetes, rat groups 


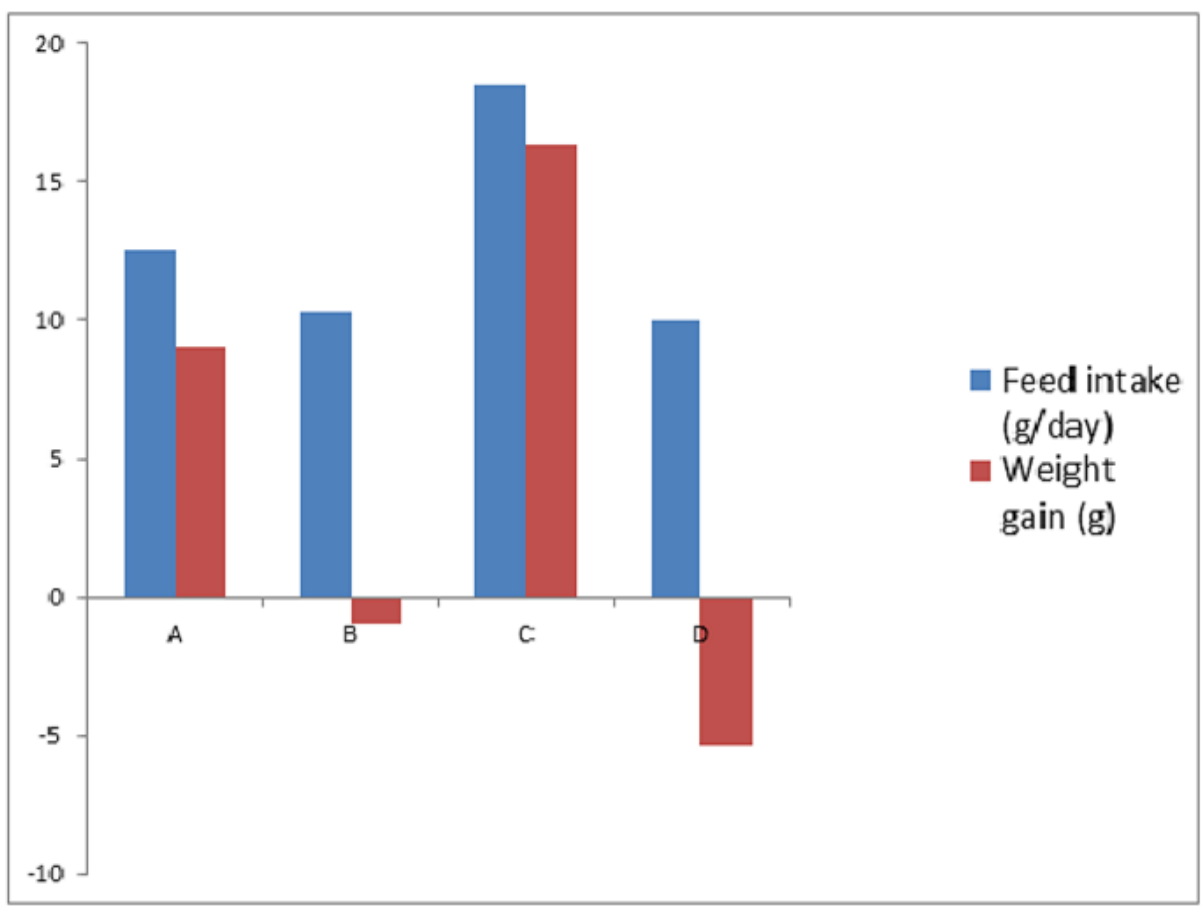

Figure 2a. Feed intake and weight gain of rats. $A=$ Non diabetic rats fed on normal diet, $B=$ Diabetic rats fed on normal diet, $C=$ Diabetic rats fed on $10 \%$ Bambara groundnut diet and D = Diabetic rat fed on Nitrogen free diet.

$B, C$, and $D$ had different glucose levels although the difference was not significant at $(p>0.05)$; the difference could be due to differences in metabolic responses in the animals. Group A rats were not induced with diabetes, hence the low glucose level result. The consumption of Bambara groundnut diet by the diabetic rats in group $\mathrm{C}$ resulted in significant reduction in blood glucose level thus signifying the importance of Bambara groundnut seed flour in ameliorating diabetes. Legumes have been reported to be rich in dietary fibre and anti-nutrients such as phytate, resulting in slow digestion and production of low glycemic index and insulin response (Duranti, 2007). Hence, they have been reported to be useful in the reduction of risks associated with cardio-vascular complications, which is thought to have multiple causes including insulin resistance and hyperglycemia (Duranti, 2007). Rats in group D were fed on Nitrogen free diet (pure starch). These group of rats had the highest blood glucose level after treatment, and this corroborates the known fact that consumption of starchy food by diabetic patient is suicidal. It has been reported that starchy food is prone to increase free radical action because it is an empty calorie without any other nutrients (Gannon and Nuttall, 2006). The result of this study is in agreement with Akinlua et al. (2013) who reported that legume seed diets have low glycemic index and this makes it suitable for use in controlling postprandial rise of blood glucose levels.

The weight gain and food intake of the rats were shown in Figure 2a. The body weight of the rats ranged between
$205 \mathrm{~g}$ in group $\mathrm{D}$ and $218 \mathrm{~g}$ in group $\mathrm{A}$. Among the diabetic groups of rats, only group C rats (fed on 10\% Bambara groundnut diet) gained weight $(16.32 \mathrm{~g})$, the weight gain was significantly higher $(p<0.05)$ than that of the control group $A$. The mean weight gain of untreated diabetic rats (group B) was significantly lower $(p<0.05)$ than the nondiabetic rats (group A). Diabetic rats treated with Bambara groundnut diet had about $80 \%$ increase in body weight over the non-diabetic rats (group A). However, the untreated diabetic rats (group B) and the diabetic rats fed on nitrogen free diet lost weight of 1.0 and $5.8 \mathrm{~g}$ respectively. It could be inferred that the Bambara groundnut added to the feed of rat group $C$ improved the sensory appeal of the rat feed, hence the higher food intake which translated to higher weight gain in this group. Animals are known to eat more food when it has good organoleptic appeal (Nnam, 2001). It has been suggested that food intake can be influenced by palatability, source of nitrogen and Essential Amino Acids (EAA) profile (Anyika et al., 2009).

The protein quality of the rat feed for different rat groups is shown in Figure $2 \mathrm{~b}$. For all quality parameters studied, the rat feed that has 10\% Bambara groundnut had significantly better quality than other feeds. Biological value (BV) gives information on how much of the absorbed Nitrogen is actually retained or utilized by the body. The result obtained in this study indicates that rats fed on $10 \%$ Bambara groundnut had the highest Nitrogen retention, hence the highest BV. Net protein utilization value (NPU) 


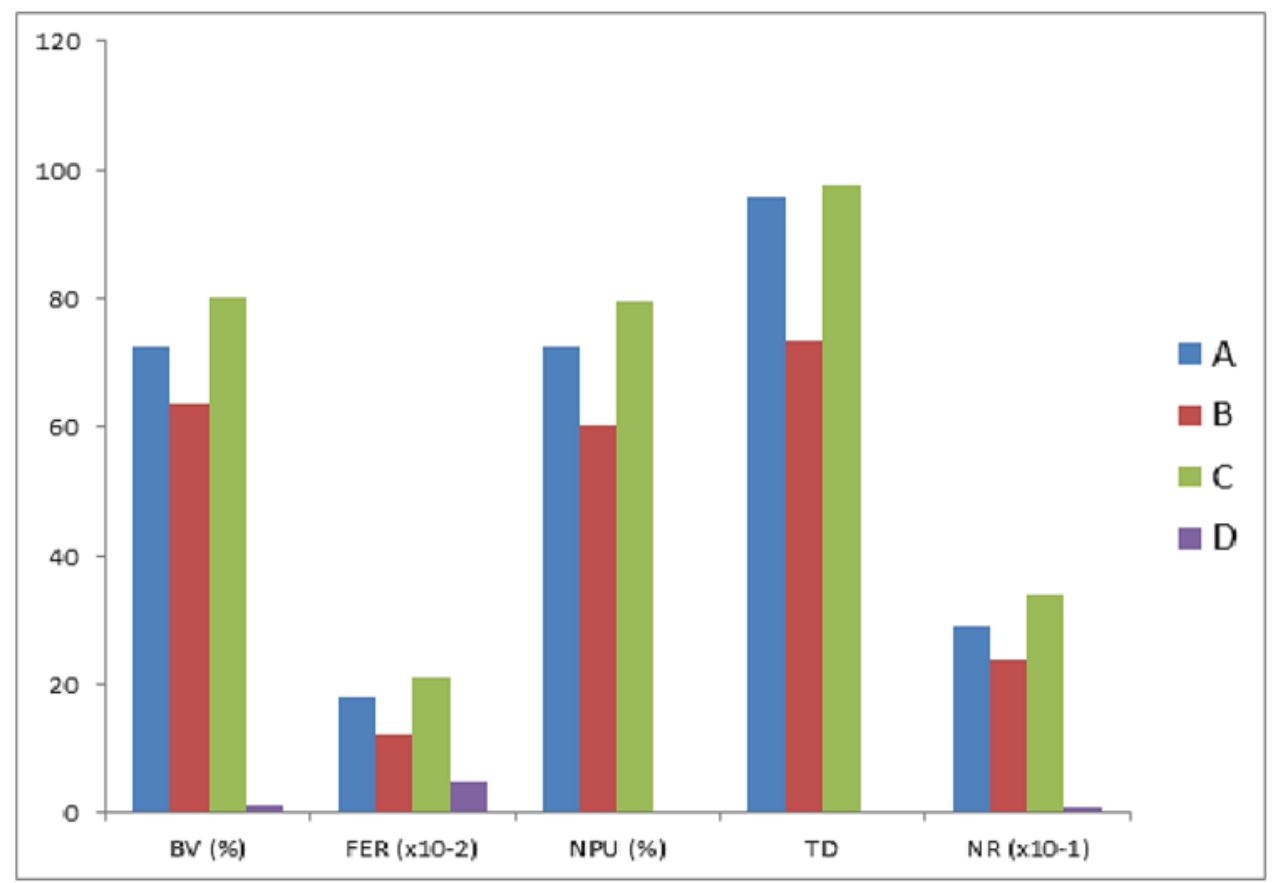

Figure 2b. Protein quality of rat feed. $A=$ Non diabetic rats fed on normal diet, $B=$ Diabetic rats fed on normal diet, $C=$ Diabetic rats fed on $10 \%$ Bambara groundnut diet and $D=$ Diabetic rat fed on Nitrogen free diet.

Table 2. Effect of Bambara groundnut consumption on some liver damage marker enzymes.

\begin{tabular}{lccc}
\hline Plasma samples & ALT (U/L) & AST (U/L) & ALP (U/L) \\
\hline A & $13.80 \pm 0.30^{\mathrm{c}}$ & $10.05 \pm 0.25^{\mathrm{b}}$ & $24.20 \pm 0.60^{\mathrm{b}}$ \\
B & $16.05 \pm 0.25^{\mathrm{a}}$ & $10.95 \pm 0.25^{\mathrm{b}}$ & $26.10 \pm 0.40^{\mathrm{a}}$ \\
C & $14.30 \pm 0.60^{\mathrm{bc}}$ & $10.05 \pm 0.45^{\mathrm{b}}$ & $24.50 \pm 0.90^{\mathrm{b}}$ \\
D & $15.85 \pm 0.55^{\mathrm{a}}$ & $11.85 \pm 0.25^{\mathrm{a}}$ & $27.00 \pm 0.20^{\mathrm{a}}$ \\
\hline
\end{tabular}

Values are means of six determinations \pm SD. Means with the same superscripts within the same column are statistically identical $(\mathrm{p}<0.05) . A=$ Non diabetic rats, fed on normal diet, $B=$ Diabetic rats fed on normal diet, $\mathrm{C}=$ Diabetic rats fed on $10 \%$ Bambara groundnut diet and $\mathrm{D}=$ Diabetic rats fed on Nitrogen free diet.

and BV are similar, while BV measures nitrogen retention from absorbed nitrogen, NPU measures nitrogen retention from ingested nitrogen. The highest value for NPU was recorded in group $\mathrm{C}$. This could be due to lower faecal and urinary Nitrogen excretion, and higher nitrogen retention (NR). The true digestibility values (TD) gives information on the percentage of nitrogen intake absorbed by the body, TD values of the non-diabetic rats on normal diet (group A), and diabetic rats treated with Bambara groundnut diet was higher than the $85 \%$ value recommended for growth (Ewuola et al., 2015). This suggests that the rat chow given to rats in the farm was of good quality, however the Bambara groundnut diet was of better quality. The quality studies is in agreement with past works on legumes (Ewuola et al., 2015; Rotimi et al., 2010; ljarotimi and Keshinro, 2012) which stated that legume consumption reduced blood glucose levels, increased growth rate and are of good quality protein. It should be noted that protein quality of animal based food is better than that of plant based foods because plant based foods do not have the complete range of amino acids (Ritcher et al., 2015).

Antioxidants are chemical substances that help to ameliorate deleterious free radicals. Superoxide dismutase (SOD) and Glutathione peroxidase (GSHPER) are endogenous anti-oxidant enzymes produced by the body. The intrinsic antioxidant enzyme system is a defense mechanism that protects cells against oxidative injury. The findings of the present study demonstrated elevated levels of AST, ALT, and ALP in diabetic induced rats (Table 2). However, treatment of diabetic rats with diet of $10 \%$ Bambara groundnut seed flour for 28 days significantly $(p<0.05)$ reversed the above parameters towards normalcy. Elevations of AST, ALT and ALP are 
Table 3. Effect of Bamabara groundnut consumption on some biomarkers of oxidative stress in plasma.

\begin{tabular}{lcc}
\hline Plasma samples & SOD $(\mathbf{U} / \mathbf{L})$ & GSHPER $(\boldsymbol{\mu m o l} / \mathbf{L})$ \\
\hline A & $809.20 \pm 0.50^{\mathrm{b}}$ & $14.30 \pm 0.90^{\mathrm{a}}$ \\
$\mathrm{B}$ & $790.10 \pm 0.40^{\mathrm{c}}$ & $13.30 \pm 0.80^{\mathrm{b}}$ \\
C & $811.05 \pm 0.25^{\mathrm{a}}$ & $15.15 \pm 0.55^{\mathrm{a}}$ \\
$\mathrm{D}$ & $806.45 \pm 1.05^{\mathrm{b}}$ & $11.95 \pm 0.45^{\mathrm{c}}$ \\
\hline
\end{tabular}

Values are means of six determinations $\pm S D$. Means with the same superscripts within the same column are statistically identical $(p<0.05) . A=$ Non diabetic rats, fed on normal diet, $\mathrm{B}=$ Diabetic rats fed on normal diet, $\mathrm{C}=$ Diabetic rats fed on $10 \%$ Bambara groundnut diet and $D=$ Diabetic rats fed on Nitrogen free diet.

Table 4. Effect of Bambara groundnut consumption on endogenous antioxidants in liver.

\begin{tabular}{lcc}
\hline Rat groups & SOD $(\mathbf{U} / \mathbf{1 0 0} \mathbf{m g})$ & GSHPER $(\boldsymbol{\mu m o l} / \mathbf{1 0 0} \mathbf{m g})$ \\
\hline A & $2113.15 \pm 0.35^{\mathrm{b}}$ & $35.85 \pm 0.60^{\mathrm{a}}$ \\
B & $1818.15 \pm 0.35^{\mathrm{c}}$ & $32.15 \pm 0.35^{\mathrm{d}}$ \\
C & $2114.95 \pm 0.35^{\mathrm{a}}$ & $35.15 \pm 0.45^{\mathrm{b}}$ \\
D & $1068.30 \pm 0.40^{\mathrm{d}}$ & $32.80 \pm 0.20^{\mathrm{c}}$ \\
\hline
\end{tabular}

Values are means of six determinations $\pm S D$. Means with the same superscripts within the same column are statistically identical $(p<0.05) . A=$ Non diabetic rats, fed on normal diet, $B$ $=$ Diabetic rats fed on normal diet, $\mathrm{C}=$ Diabetic rats fed on $10 \%$ Bambara groundnut diet and $D=$ Diabetic rats fed on Nitrogen free diet.

attributed to hepatocellular damage and decreased liver functions as has been previously reported by Ahmed et al. (2018). The highest levels of SOD and GSHPER were found in rat group $\mathrm{C}$ (the group on 10\% Bambaragroundnut diet), there was increased activities of SOD and GSHPER in diabetic untreated rats (Table 3). This result implies that the rats in group $C$ exhibited the least oxidative stress, while the rats in group $B$ had the highest oxidative stress. Rotimi et al. (2010) also observed decrease in the activities of SOD and GSHPER in kidneys of diabetic rats. Excessive oxidative stress had been reported to suppress the activity and expression of endogenous enzymes (Ceriello, 2000). The results obtained in this study suggest the modulation of oxidative stress by Bambara-groundnut diet, which may be due to their high antioxidant capacity as reported by Ademiluyi and Oboh (2012).

Liver is a central organ for metabolism. It is a major organ attacked by reactive oxygen species (ROS). GSHPER and SOD participates in the cellular defense system against oxidative stress by scavenging free radicals and reactive oxygen intermediates. The trend observed for plasma SOD and GSHPER was also observed in the liver of the rats. Diabetes caused marked depletion of endogenous antioxidants (SOD and GSHPER) in diabetic rats on normal diet (group B) i.e diabetic untreated rats; however, the rats fed on $10 \%$ Bambara-groundnut diet (group C) had their levels of SOD and GSHPER brought close to that of the non-diabetic rats in the control group A. The result is in agreement with past works (Rotimi et al., 2010; Ademiluyi et al., 2010). Increased activities of SOD and GSHPER in Group C indicated that the rats in this group had minimal oxidative stress (Table 4). Alterations in the endogenous free radical scavenging defense mechanisms (associated with diabetes mellitus) could lead to ineffective scavenging of reactive oxygen species, resulting in oxidative damage and tissue injury.

\section{Conclusion and recommendation}

The result obtained in this work revealed that consumption of Bambara groundnut seed diet up-regulated endogenous antioxidant levels thereby ameliorating oxidative stress in diabetic rats. Regular consumption of Bambara groundnut based diet as a strategy in diabetes management is therefore recommended.

\section{CONFLICT OF INTEREST}

The authors declare that they have no conflict of interest.

\section{REFERENCES}

Ademiluyi, A. O., \& Oboh, G. (2012). Attenuation of oxidative stress and hepatic damage by some fermented tropical legume condiment diets in streptozotocin-induced diabetes in rats. 
Asian Pacific Journal of Tropical Medicine, 5(9), 692-697.

Ademiluyi, A. O., Oboh, G., \& Ademosun, A. O. (2010). Antixoxidant properties of soy daddawa: A condiment produced from fermented soybean (Glycine max L Merrill). La Rivista Italiana delle sostanze Grasse, 87, 226-235.

Ahmed, Z., Ahmed, U., Walayat, S., Ren, J., Martin, D. K., Moole, H., Koppe, S., Yong, S., \& Dhillon, S. (2018). Liver function tests in identifying patients with liver disease. Clinical and Experimental Gastroenterology, 11, 301-307.

Akinlua, O., Sedodo, N. S., \& Victoria, A. J. (2013). Glycaemic index of selected Nigerian foods for apparently healthy people. Journal of obesity and weight loss therapy, 3, 160-164.

Anyika, J. U., Obizoba, I. C., \& Nwamarah, J. U. (2009). Effect of processing on the protein quality of African Yambean and Bambara groundnut supplemented with sorghum or crayfish in rats. Pakistan Journal of Nutrition, 8(10), 1623-1628.

AOAC (2000). Official methods of Anlysis. Association of Official Analytical Chemists. Washington, D.C. 16th edition.

Bamshaiye, O. M., Adegbola, J. A., \& Bamishaiye, E. I. (2011). Bambara groundnut: an under-utilized nut in Africa. Advances in Agricultural Biotechnology, 1(1), 60-72.

Ceriello, A. (2000). Oxidative stress and glycemic regulation. Metabolism, 49(2), 27-29.

Directorate Plant Production (DPP) (2011). Production guidelines for Bambara groundnuts. Pretoria, South Africa: Department of Agriculture, Forestry and Fisheries. Pp. 1-10.

Duranti, M. (2007). Grain legume proteins and Nutraceutical properties. Fitoterapia, 77, 67-82.

Ejike, C. C., UKa, N. K., \& Nwachukwu S. O., (2015). Diabetes and pre-diabetes in adult Nigerians: Prevalence, and correlations of blood glucose concentrations with measures of obesity. Academic Journal, 9(3), 55-60.

Ewuola, G. O., Ibironke, S. I., \& Fashakin, J. B. (2015). Formulation and nutritional evaluation of maize, Bambara groundnut and cowpea seeds blends complimentary food. American Journal of Food and Nutrition, 3(4), 101-105.

Farinde, E. O., Olanipekun, O. T., \& Olasupo, R. B. (2018). Nutritional composition and anti-nutrients content of raw and processed lima bean (Phaseolus lunatus). Annals, Food Science and Technology, 19(2), 250-264.

Gannon, M. C., \& Nuttall, F. Q. (2006). Control of blood glucose in type 2 diabetes without weight loss by modification of diet composition. Nutrition and Metabolism, 3(1), 16-21.

Harris, T., Jideani, V., \& Le Roes-Hill, M. (2018). Flavonoids and Tannins composition of Bambara groundnut (Vigna subterenea) of Mpumalanga, South Africa. Heliyon, 4(9), 8388.

ljarotimi, O. S., \& Keshinro A. A. (2012). Formulation and nutritional quality of infant formula produced from germinated popcorn, bambara groundnut, and African locust bean flour. Journal of Microbiology, Biotechnology and Food Scence, 1(6), 1358-1388.

Jadela, R. N., Devkar, R. V., \& Nammi, S. (2017). Oxidative stress in Liver diseases: Pathogenesis, Prevention, and Therapeutics. Oxidative Medicine and Cellular Longevity, 1, 10-11.
Jarald, E. E., Joshi, S. B., Jain, D. C., \& Edwin, S. (2013). Biochemical evaluation of hypoglycaemic effect of extract and fraction of Cassia fistula Linn. in Alloxan -induced diabetic rats. Indian Journal of Pharmaceutical Science, 75(4), 427-432.

Jideani, V. A., \& Diedricks, C. F. (2014). Nutritional, therapeutic and prophylactic properties of Vigna subterranean. In: Antioxidant-antidiabetic agents and Human health. IntechOpen. Pp. 187-207.

Koné, M., Paice, A. G., \& Touré, Y. (2011). Bambara groundnut [Vigna subterranea (L.) Verdc. (Fabaceae)] usage in human health. In: Nuts and Seeds in Health and Disease Prevention (edited by V.R. Preedy, R.R. Watson and V.B. Patel). UK: Elsevier Inc. Pp. 192-194.

National Institute of Health (NIH) (2011). Guide for the care and use of Laboratory animals. 8th edition. National Research Council (US) Committee for the update of the Guide and use of Laboratory animals. Washington DC. National Academies Press (US). p. 21

Nnam, N. M. (2001). Comparison of the protein nutritional value of food blends based on sorghum, Bambara groundnut and sweet potatoes. International Journal of Food Sciences and Nutrition, 52(1), 25-29.

Oboh, G. (2006). Nutrient and antinutrient composition of condiments produced from some fermented underutilized legumes. Journal of Food Biochemistry, 30(5), 579-588.

Olokoba, A. B., Obateru, O. A., \& Olokoba, L. B. (2012) Type 2 Diabetes Mellitus: A review of current trends. Oman Medical Journal, 27(4), 269-273.

Oztassan, N. (2013). The effects of Yucca shidigera on blood glucose and lipid levels in diabetic rats. African Journal of Biochemistry Research, 7(9), 179-183.

Ritcher, C. K., Skulus-Ray, A. C., Champagne, C. M., \& KrisEtherton, P. M. (2015). Plant proteins and animal proteins: Do they differentially affect cardiovascular disease risk? Advances in Nutrition, 6(6), 712-728.

Rotimi, S. O., Olayiwola, I., Ademuyiwa, O., \& Adamson, I. (2010). Inability of legumes to reverse diabetic-induced nephropathy in rats despite improvement in blood glucose and antioxidant status. Journal of medicinal food, 13(1), 163-169.

Salim, S. (2017). Oxidative stress and the central nervous system. Journal of Pharmacology and Experimental Therapeutics, 360(1), 201-205.

Winterbourn, C. C., Hawkins, R. E., Brian, M., \& Carrell, R. W. (1975). The estimation of red cell superoxide dismutase activity. The Journal of Laboratory and Clinical Medicine, 85(2), 337-341. 